\title{
Strawberry Genetics.
}

\author{
G.J. Galletta and J.L. Maas \\ Agricultural Research Service, U. S. Department of Agriculture, Fruit Laboratory, PSI BARC- West, \\ Beltsville, MD 20705
}

There have been several comprehensive English language historical reviews of strawberry genetics and improvement, notably those of Darrow (1937, 1966) and Scott and Lawrence (1975). Gaining an understanding of strawberry genetics is complicated by varying species ploidy levels, hybrid origin of several of the polyploid species, and a combination of discontinuous (discrete or Mendelian) and continuous (quantitative or multifactorial) inheritance patterns for various traits within the same plant.

Genetic exchange within and among species in the genus Fragaria is further limited by sexual dimorphism in some of the species, and by partial or complete cross-incompatibility in both heteroploid and in some homoploid hybridizations. Fortunately, exchange among the octoploid species, including the garden or cultivated strawberry and its ancestral American parent species, is relatively unrestricted.

An attempt will be made in this review to outline major trends in strawberry genetics research since the Scott and Lawrence paper, or roughly the period from 1970 to 1989 . Cytogenetic, evolutionary, and ecological facets of the strawberry genetics picture will be treated lightly, or not at all, because these topics will be treated by others in this series.

\section{BREEDING SYSTEM CHARACTERIZATIONS}

This active area of inquiry consists of continuing studies that determine the amount of genetic diversity present in a population, largely for selecting parents for the next generation of improvement. Populations of strawberry clones are grown under certain environmental conditions or are subjected to artificial or natural screening to discern the phenotypic response(s) of each clone. Many times it may be necessary to partition a character (or set of characters) into their components before selection. These components may then be analyzed for heritability. In the process of the heritability analysis, clones are identified that possess good or poor combining ability. Further, the presence of significant amounts of additive and nonadditive genetic variance suggests which breeding strategies may be particularly successful.

\section{Genetic diversity}

Narrow genetic bases for cultivars of our principal food crops has become a matter of increasing concern and has stimulated considerable recent germplasm exploration, collection, and evaluation. Sjulin and Dale (1987) analyzed a population of 234 North American strawberry cultivars introduced between 1960 and 1985 for genetic diversity. They demonstrated that the strawberry is in a better position than many crops, in that 53 "founding clones" contributed genetic materials to the 134 cultivars. These founding clones (originated in the 19th and 20th centuries) had mean genetic contributions of $<0.1 \%$ to $11 \%$. The extensive use of the 'Howard 17 ' clone as a parent led to the contribution of seven founding clones (all in the 'Howard 17' parentage) to at least 130 of the 134 cultivars. The cultivars were clustered by genetic parent contribution into 11 groups that were strongly related to area of geographic origin. Inbreeding coefficients were calculated for the 134 cultivars, and they varied from 0.0 to 0.875 . Three suggested strategies for maintaining and increasing genetic diversity in genetic improvement programs were: a) increasing the number of parents per generation, combined with a controlled system of mating; b) introduction of partially or completely unrelated $F . \times$ ananassa germplasm into the breeding population; and c) introducing unimproved germplasm from wild Fragaria species. Such measures have been adopted by many genetic improvement programs and are important in a species where one cycle of self-pollination will reduce vigor, yield, and fruit size. 
Table 1. Examples of parent source character identification in strawberries during the period 1970-1989.

\begin{tabular}{|c|c|c|}
\hline Trait & Literature source & Possible parent clones \\
\hline Aphid resistance (virus vectors) & Crock et al., 1982 & $\begin{array}{l}\text { 'Benton', 'Del Norte', and } 29 \text { clones in North American } \\
\quad F . \text { chiloensis }\end{array}$ \\
\hline $\begin{array}{l}\text { Starch gel electrophoresis isozyme pat- } \\
\text { terns of PGI, LAP, and PGM }\end{array}$ & Bringhurst et al., 1981 & Separation of 14 of 22 cultivars into unique classes \\
\hline Two-spotted spider mite tolerance & Shuster et al., 1980 & 'Florida Belle', 'Sequoia' \\
\hline Root-knot nematode tolerance & Edwards et al., 1985; Szczygiel and Danek, 1984 & $\begin{array}{l}\text { 'Apollo', 'Earliglow', 'Prelude', 'Glima', 'Senga Sen- } \\
\text { gana' }\end{array}$ \\
\hline Berry mold resistance & Popova et al., 1985 & $\begin{array}{l}\text { 'Badgerglo', 'Troubadour', 'Atlas', 'Arnika', 'Red- } \\
\text { gauntlet,, 'Holiday', 'Oreshuk', 'Kulon', Zh 16-223 }\end{array}$ \\
\hline $\begin{array}{l}\text { Resistance to strawberry root weevil and } \\
\text { black vine weevil }\end{array}$ & $\begin{array}{l}\text { Maas and Smith, } 1978 \\
\text { Shanks et al., } 1984\end{array}$ & $\begin{array}{l}\text { 'Earliglow' } \\
\text { A number of native North American } F \text {. chiloensis clones, } \\
\text { especially CL-5 and GCL-8 }\end{array}$ \\
\hline $\begin{array}{l}\text { Adaptation to mechanization and fruit } \\
\text { quality }\end{array}$ & Sistrunk and Moore, 1980 & 'Cardinal' and A-5344 \\
\hline Jam production & Skrede, 1980 & 'Jonsok', 'Totem', 'Bounty', 'Senga Sengana' \\
\hline Freezing quality & Daniels et al., 1982 & 'Darrow', 'Earliglow', 'Vesper' \\
\hline Resistance to red stele root rot & Maas et al., 1989 & $\begin{array}{l}\text { Eastern U.S. cultivars resistant to scveral Wcstern U.S. } \\
\text { red stele races; 'Darrow', 'Delite', 'Earliglow', } \\
\text { 'Guardian', 'Lateglow', 'Midway', 'Scott', 'Spar- } \\
\text { kle', 'Surecrop', 'Tribute', 'Tristar' }\end{array}$ \\
\hline Verticillium wilt resistance & Maas et al., 1989 & $\begin{array}{l}\text { High resistance: MD-683, 'Del Norte', 'Aberdeen'; } \\
\text { moderate resistance: 'Midway', 'Pocahontas', 'Su- } \\
\text { recrop', 'Guardian', 'Tristar', 'Tribute', 'Micmac', } \\
\text { 'Delite', 'Earliglow', 'Lester', 'Lateglow' }\end{array}$ \\
\hline Virus tolerance & Daubeny et al., 1972 & $\begin{array}{l}\text { 'Totem', 'Northwest', 'Cheam', BC26, BC5, WSU1054, } \\
\text { 1165, 1169, 1217, 1232, 1238; 'British Sovereign', } \\
\text { 'Cambridge Favourite' }\end{array}$ \\
\hline
\end{tabular}

\section{Cytogenetics}

A considerable body of quantitative genetic data for the cultivated strawberry octoploid species is based on the assumption of regular diploid bivalent pairing during meiosis. Early chromosome association studies by Ichijima (1926), Longley (1926), and Powers (1944) suggested that this assumption was correct. Later observations by Staudt $(1951,1952)$ with the hexaploid species $F$. moschata and the tetraploid species $F$. orientalis showed mutlivalent associations present at diakinesis, but their terminalization into bivalents by Metaphase I. Mok and Evans (1971), in an attempt to determine the probability of polysomic inheritance in strawberry cultivars, studied diakinesis of nine eastern North American cultivars. They found multivalent pairing in each of the nine cultivars in each of 2 years, varying from quadrivalents and hexavalents to occasional octovalents. Bivalent pairing varied in closeness of association and some secondary pairing was observed. The authors concluded that tetratomic inheritance is likely to be important in the cultivated strawberry. However, they noted that the rest of the meiotic cycle appeared normal.

Byrne and Jelenkovic (1976), studying chromosome pairing of nine cultivars and $32 \mathrm{~S}_{1}$ seedlings of $F$. xananassa, reported all chromosome pairing as bivalents, indicating cytological diploidization. Five cells with apparent multivalents were interpreted as pseudomultivalents because of their end-to-end or side-to-side associations rather than the typical ring and chain multivalent associations. A completely sterile seedling was found to have complete bivalent pairing at pachytene, but desynapsis to an almost completely unpaired condition by diplotene. Pentaploid hybrids between F. Xananassa and the unrelated diploid species $F$. nubicola averaged 11.6 bivalents per PMC and frequent multivalent associations, indicating a residual homology between ancestral genomes of the octoploid strawberry. The usual lack of pairing among homologous chromosomes in the cultivated strawberry was attributed by the authors 'to a genetic control leading to preferential pairing of homologous chromosomes within genomes. (Also, selection by breeders for highly fertile types probably automatically results in a correlated selection for regular bivalent pairing and disjunction.)

A later chromosome pairing study of four strawberry $(8 \mathrm{x})$ seedling progenies cultivated in Iowa and their parent clones (Ibrahim et al., 1981) agreed with the findings and interpretations of Byrne and Jelenkovic (1976) of complete bivalent pairing with some sec- ondary association of bivalents as pseudo-multivalents.

Berezenko $(1976,1981)$ made comparative studies of meiosis in a group of sterile garden strawberry (8x)-hautboy strawberry $(6 x)$ hybrids and their parent clones. Meiosis was essentially normal in the parent clones. The heptaploid $(7 \mathrm{x}, 2 \mathrm{n}=49)$ sterile hybrids exhibited the following abnormalities: presence of univalents, trivalents, tetravalents, and pentavalents at diakinesis; cytomixis during Prophase I; chromosome alignment off the spindles and premature chromosome movement to the poles in Metaphase I and Anaphase I; laggards at Anaphase I; and chromosome ejection into the cytoplasm at Telophase I. These abnormalities were repeated during the second meiotic division, leading to abnormal spore numbers and sterile pollen grains. In the 1981 paper, the proportion of large (diploid) and small pollen grains are characterized for size and shape for each hybrid.

\section{Parent source identification}

It is always critical to have parent sources for particular characteristics identified so that future genetic recombination and selection is possible. Considerable progress was made in this period in identifying parents for diverse strawberry traits (Table 1).

\section{Correlated phenotypic traits}

Character component studies, which identify and assess the genotypic and environmental influences on the expression of correlated phenotypic traits, are becoming more frequent. Knowledge about correlated traits is most important to the strawberry geneticist, because selection can be directed to improving individual aspects of a complex character such as fruit yield or appearance more readily than the entire characteristic. For example, the resistance of $F$. chiloensis clone CL-5 to feeding by adult black vine weevils was traced to the dense covering of simple hairs on abaxial leaf surfaces of this clone (Doss et al., 1987).

The strength of expression of the day-neutral (everbearing) character was related to plant structure (Nicoll and Galletta, 1987). Strong, or continuous-blooming, day-neutrals are basically small plants with below-average numbers of leaves and meristems and an average number of crowns with high meristem development as flower trusses. Intermediate, or periodic-blooming, day-neutrals are small to medium leafy plants with many crowns and axillary meristems. 
Table 2. Quantitative inheritance of strawberry traits in the period 1970-1989. (Outstanding parents and crosses are identified by the authors in combining analysis studies.)

\begin{tabular}{ll}
\hline \hline $\begin{array}{l}\text { Trait(s) and } \\
\text { references }\end{array}$ & Breeding materials \\
\hline $\begin{array}{l}\text { Seed germination and seedling vigor } \\
\text { (Melville et al., 1980b) }\end{array}$ & $\begin{array}{l}\text { Intercrossed, selfed, outcrossed population of two } S_{1}, \\
\text { two } S_{2} \text { and two non-inbred selections }\end{array}$ \\
& -
\end{tabular}

Red stele resistance (Melville et al., 1980a)

Same as Melville et al. (1980b); six-parent diallel

Aphid resistance (Barritt and Shanks, 1980)

Cornicle (Infl?) no., Flowering time per plot (beginning), yield (total wt.) (Ulyukin et al., 1976)

Twospotted mite resistance (Barritt and Shanks, 1981)

Powdery mildew resistance (Simpson, 1987)

Leaf spot resistance (Shaw et al., 1988)

Fruit quality factors taste, consistency, anthocyanin content, vitamin $\mathrm{C}$ content, R-active catechin content (Zubov and Stankevich, 1982)

Primary : secondary fruit size relationship (Pelofske and Lawrence, 1984)

Fruit detachment traits (Brown et al., 1975)

Easy calyx removal (Barritt, 1976)

Mathine harvesting (Lawence and Martin, 1980)

Harvest mechanization (Moore and Sistrunk, 1980)

Virus tolerance (Barritt and Daubeny, 1982)

Virus toleránce (Sjulin et al., 1986)

Fruit yield and related characters (Aalders and Craig, 1974)

Root-knot nematode resistance (Szczy- Seven cultivar crosses. giel and Danek, 1984)

Soluble solids, titratable acidity, and fruit firmness (Shaw et al., 1987)

Sugars and organic acids (Shaw, 1988)
Five clones and two $\mathrm{BC} 1$ seedling progenies from $F$. chiloensis 'Del Norte'

Six cultivars diallel, 28 progenies, three blocks with two replications per plock, 80 seedlings per plot

Fifteen crosses involving three cultivars and five selections two locations in field and greenhouse

Four everbearing and three short-day cultivars in a half diallel w/o selfs (Expt. 1) Expts. 2-5 EB and DN clones crossed to eight short-day clones

Two years -66 crosses from 18 parents with 15 reciprocals; 2nd year -30 crosses from 14 parents

Five parent diallel, 20 progenies, four replications of 100 seedlings in a lattice design

Seventeen cultivars and selections, six crosses -50 seedlings per cross

Seven clones and six crosses

Twenty-seven clones and 79 seedling families

Thirty-seven cultivars and selections parent evaluation for transmission

Review of progress and characters

Twenty-nine progenies + parent clones RCB, six replications, five scedlings per replication

Four-parent diallel + parents, excluding selfs, all test plants inoculated by virus-bearing aphids

Diallel of seven inbred clones

Twenty-eight crosses among 16 parents from California breeding population

Twenty-five selections in two sets
Findings $^{2}$

Most intercrossed and outcrossed inbreds had similar germination, germination rate, and shoot and roo weights as the non-inbred control cross. Selfs had lower vigor than most intercrosses. The $S_{3}$ progeny had lower germination total and rate than the control.

Level of inbreeding and type of inbred cross was not related to transmission of red stele resistance. Selfpollinations transmitted less resistance than crosspollinations. There was significant SCA for weighted progeny mean score and for percent resistant.

Segregation occured in $\mathrm{BC} 1$ generation. Resistant clones were selected from both crosses, but they did not have quite as high a level of resistance as the source clone.

Cornicle no. and flowering time were GCA significant; yield was GCA and SCA significant. No reciprocal effects seen in these characters.

GCA and SCA significant at both locations for mean no. of mites/leaflet. GCA > SCA. Heritabilities (parent/offspring regressions) were high. Additive genetic variance important in mite resistance.

Expt. $1 \mathrm{GCA}$ and SCA significant in both years. GCA SCA. Expt. 2. findings same as Expt. 1-additive and non-additive gene effects important.

0-5 scalar scores, significant GCA and SCA, heritabilities improve with seasonal progression. Genetic gain is improved by multistage rather than mass selection.

Significant differences among seedlings for all characters except taste. GCA and SCA significant for other four characters GCA > SCA except for vitamin C.

Frequency distributions of $\mathrm{P}: \mathrm{S}$ ratios within progeny and comparison with parent and midparent values indicates quantitative inheritance.

Capping force, capping percent, and pedicel breaking force evaluated. $F$. virginiana is an excellent capping source. Progeny means for pedicel breaking were near the low parent mean.

GCA and SCA significant GCA $4 \times$ SCA. Heritability estimate $0.84 \mathrm{GCA}$ correlated with parent phenotype $(r=0.828)$.

Evaluated traits: Capping ease-'Olympus' and ORUS 4637 most effective parents; concentrated ripening, fruiting habit-'Totem', 'Benton', ORUS 4637, and ORUS 4003 transmitted good fruit support.

Important characters: Concentrated ripening, productivity, easy fruit detachment, firmness, color, processing quality. 'Cardinal' released, prepotent selections for the other traits identified.

'Totem' and Aiko' produced the highest proportion of tolerant seedlings. GCA and SCA signficant. GCA $>$ SCA. Heritability when disease was worst was 0.73 .

Inoculated plants had reduced vigor, petiole length, leaf width, leaf dry wt., and more leaves than controls. GCA significant for all characters.

Total yield: Nonadditive significant factor. Berry wt: Nonadditive and additive significant. Runner no.: Both are significant. Plant area: Nonadditive significant.

'Glima' was prepotent for transmitting galling index lowering and increasing the number of seedlings without galls. Seedling and mature reactions werc well-correlated.

Narrow-sense heritabilities; $0.07,0.48$, and 0.38 for solids, acid, and firmmess, respectively. Broad-sense hertiabilities: $0.35,0.78$, and 0.38 for the same traits suggest dominance variation for solids and acids, but not for firmness.

Gentoypic variation and corrclation estimated for soluble solids, titratable acidity, and their major constituents. Genotypic variation was significant for sucrose, glucose, and fructose, but not for total sugars or solids. Genotypic variation for acids is large.

(continued) 


\begin{tabular}{|c|c|c|}
\hline $\begin{array}{l}\text { Trait(s) and } \\
\text { references }\end{array}$ & Breeding materials & Findings ${ }^{z}$ \\
\hline $\begin{array}{l}\text { Early flowering in day-neutrals (Barritt et } \\
\text { al., 1982) }\end{array}$ & $\begin{array}{l}\text { Fifty-four crosses between day-neutral and short-day } \\
\text { clones }\end{array}$ & $\begin{array}{l}\text { Percent flowering by September and earliness of flow- } \\
\text { ering evaluated. Crosses producing the highest pro- } \\
\text { portion of day-neutrals also produced the highest } \\
\text { proportion of early flowering. GCA was more im- } \\
\text { portant than SCA in early flowering. }\end{array}$ \\
\hline Autumn fruiting (Jennings, 1989) & $\begin{array}{l}\text { Three nisqually progenies subjected to principal } \\
\text { component analysis. }\end{array}$ & $\begin{array}{l}\text { Two vectors were identified-one describing the neg- } \\
\text { ative association between reproductive and vegetative } \\
\text { vigor, and another that describes vegetative vigor in- } \\
\text { dependent of reproductive vigor. This makes possible } \\
\text { the identification of vegetatively vigorous autum- } \\
\text { fruiting types, and supports the idea of two distinct } \\
\text { types of response to photoperiod-temperature factors } \\
\text { that are conditioned by major genes. }\end{array}$ \\
\hline
\end{tabular}

${ }^{{ }^{\mathrm{GCA}}}=$ general combining ability (additive genetic variance); $\mathrm{SCA}=$ specific combining ability (nonadditive genetic variance) .

Meristem development is medium, basically as flower trusses and branch crowns. Weak day-neutrals (sporadic bloomers) are large plants with few leaves, crowns, or meristems. However, a high proportion of the axillary buds develop into runners.

Many studies correlated vegetative and reproductive trait performance during this period (Nicoll and Galletta, 1987; Strik and Proctor, 1988; Lal and Seth, 1980; Lacey, 1973; Swartz et al., 1982; Hancock et al., 1982; Popenoe and Swartz, 1985; Swartz et al.,, 1985; Durner and Poling, 1986). (There are more references to yield component studies in the literature cited in these papers.)

Basically, a strawberry cultivar needs to be planted at the proper time and spacing, with sufficient nutrients and moisture available, to develop enough plant body and flower bud. initiation sites to permit maximum flower bud initiation and development, fruit set, and fruit maturation. There are distinct genotype-cultural system interactions.

For winter and early spring production in the intensive double or quadruple hill, raised bed, clear polyethylene-mulched California growing system, selection has been directed to clones that produce many flowers continually at low temperatures, while growing very slowly as temperatures increase. Selection has also emphasized ability to mature and size attractive fruit under a variety of climatic stresses (R.S. Bringhurst, personal communication).

In the rest of the United States and Canada, and in Europe and Asia, where a variety of cultural systems are used, the vegetativereproductive interactions for each cultivar are more complex. There are significant positive correlations, usually between yield and fruit number, inflorescence number, leaf number, and crown number. There are often negative correlations between yield and plant size or volume, root size, leaf area, petiole length, and runner number (Nicoll and Galletta, 1987).

Yield is the product of its primary components-fruit number and fruit size. Fruit number and fruit size are negatively related, and fruit number is more important to yield. The influence of plant size and leaf number on yield varies with time of year (Lacey, 1973).

La1 and Seth (1981) partitioned their correlation values into phenotypic, genotypic, and environmental contributions. Fruit yield was negatively correlated with runner number and positively correlated with days to runner formation, inflorescence number, fruit number, fruit length and diameter, and number of achenes. Fruit number (genotypic) was positively correlated with leaf number, inflorescence height, inflorescence number, and total soluble solids, and negatively correlated with flower size and fruit diameter. Fruit length was genotypically negatively correlated with leaf number, runner number, inflorescence height, soluble solids concentration, and fruit number, and positively correlated with days to runner formation, days to maturity, fruit diameter, and number of achenes. Fruit diameter was negatively correlated with leaf number, runner number, inflorescence height, and total soluble solids content, and positively related to days to runner formation, days to flowering, days to maturity, fruit length, and achene number. Achene number was negatively related to runner number, and positively related to days to runner formation and ascorbic acid, in addition to fruit length, diameter, and yield.

Strik and Proctor (1988) studied genotypes with diverse yield potentials in matted rows and as single plants. Within genotypes, yield per plant mainly depended on fruit number in either cultural system. Potential yield differences within genotypes are apparently established before or during flower bud differentiation. Vegetative variables were highly correlated with yield when the genotypes were grown as matted rows. When grown singly with less interplant competition, reproductive variables were correlated with yield among genotypes. In some genotypes, runnering and fruiting may have competed for assimilates. Genotypic yield variability suggested that genotypes with similar yield can have different routes to yield.

Swartz et al. (1982) studied plant crown competition effects of several cultivars in matted rows with the same bed configuration in one year and variable configurations in the second year. In the same bed configuration trial, yield differences among genotypes on an area basis were equalized on a per-crown basis because cultivar differences among various yield components tended to balance. Narrow beds were more productive than wide beds. There were no yield differences in raised vs. flat beds. At high plant densities, intercrown competition reduced the number of inflorescences per crown, percentage fruit set, and fruit weight. Flower density was a better predictor of fruit set than crown density. Fruit weight correlated negatively with increased crown, flower, and fruit densities, contributing to reduced fruit yields per crown. Yield per square foot $\left(0.09 \mathrm{~m}^{2}\right)$ was maximized at crown densities of six or 12 crowns per square foot in the 2 years, when yield per crown was regregressed onto crowns per square foot.

Hancock et al. (1982) demonstrated genotypic variation in yield response to plant spacing and runner removal. Popenoe and Swartz (1985) cataloged yield component shifts in two genotypes across two growing seasons for five cultural systems. Durner and Poling (1986) showed genotypic variation in crown productivity of fruit at various spacings. Swartz et al. (1985) characterized 14 cultivars and breeding selections for yield component differences in leaf productivity, fruit set, fruit weight, yield per inflorescence, per plant crown, per plant, and per acre. Again, high yields were produced by various genotypes in diverse manners. Regressions of various of the yield components produced several predictive equations for evaluating genotype performance in wide or narrow matted row culture.

\section{BREEDING SYSTEM MANIPULATIONS}

Recently, experiments have been performed to manipulate or change the strawberry system by intergeneric or species hybridizations or by in vitro culture of strawberry plant parts. In some cases, the objective was to introduce exotic germplasm into the strawberry; in 
Table 3. Genetic variation studies with strawberries, 1970-1989.

\begin{tabular}{ll}
\hline \hline Author(s) & Methods \\
\hline Watkins and Spangelo (1971) & $\begin{array}{l}\text { Additive and nonadditive variance limiting values, calcu- } \\
\text { lation of discriminant function selection index for seven } \\
\text { characters, two-step selection - progeny and individual }\end{array}$
\end{tabular}

Spangelo et al. (1971)

Heritability and genetic variance for 20 characters in 64 progenies involving 31 North American and one German clone. North Carolina design II crossing scheme. Random and mixed models

Gooding et al. (1975)

Two locations, $8 \times 8$ partial diallel to identify parents that transmit yield stability and its components, and to identify genotypes prone to barrenness. GCA, SCA, years, sites, G/E interactions

Hortynski (1979)

Lal and Seth (1979) Twenty samples per cultivar. Variance partitioning, heritability, and genetic advance calculated for 15 characters

Wenzel (1980)

Four character analyses of five RCB experiments, each containing at least 18 genotypes and five replications. Phenotypic and genotypic correlations, selection indices, and expected genetic responses

Hortynski (1980)

Lal and Seth (1981)

Fifteen full-sib random progenies ( 450 seedlings) RCB, three replications, Griffings random model genetic variance, broad-sense heritability, genetic variance analysis-hierarchial, random model, upper limits of heritability-repeatability coefficient, 3 years

$10 \times 10$ Complete diallel, GCA and SCA recorded, Griffings method $I$, model $I$. Ninety $F_{1}$ and $F_{2}$ progenies, four character analysis

Lal and Seth (1982)

Hortynski (1989)

Same methods as 1981, five different characters: fruit length, diameter, weight, yield, and total soluble solids concn.

Genotype-environment interaction analyses using three
Thirty cultivars from North America, Europe, and India

Characters and major findings

Mildew resistance, flower stalk no., fruit appearance, fruit no., marketable yield, leaf scorch, and processing desirability - as much as $40 \%$ of the total genetic variance was nonadditive for an average of the seven characters and the index.

Yield-total, mkt., late, late mkt., three high picks (HPK), Berry no., berry wt*., fruit/stalk* , yield/stalk, flower stalk\#, petiole no., petiole diam., vigor, first pick No. of three HPK, firmness, easy capping, ext. appear., inter. appear., $\mathrm{pH}^{*}$, soluble solids*. than $50 \%$ of genetic variance non-additivc.

* = high heritability, or over $37 \%$.

Plant size, crown no., infl./crown, fruit/infl., fruit size, estimated yield. Site had a major effect on inflorescences per crown (I/C). Low I/C was partially compensated by greater Fr/I. Site had a minor effect on fruit size. Site and GCA effects were more important than their interactions; hence, total yield and high $\mathrm{Fr} / \mathrm{I}$ were less influential in yield stability than selection for High $\mathrm{I} / \mathrm{C}$.

Seedling yield was best determined $(R=0.96)$ by a combination of the components fruit no., flowers/inflor., and fruit wt. Seedling size and vigor and leaf area during harvest or the preceeding fall were also influential $(R=$ 0.61 and 0.53 , respectively). Environmental influences were high in correlations between yield and vegetative characters.

High GA $+\mathrm{H}=$ additive gene effects for leaf, inflorescence, fruit and achenc numbers and fruit yield. Nonadditive effects for runner no., days to runner formation, flowering, or ripening, inflor, height, flower or fruit size, soluble solids or vitamin $\mathrm{C}$.

Yield (Y), berry size (S), freezing ability (FA), and total soluble solids concn. (SS). Correlations:-Positive : Y-S; S-FA; Negative: SS and Y, S, and FA. Selection indices did not aid in yield advances expected responses, but aided in selection of desirable genotypes for all characters.

Seven plant size, vigor, and leaf area components; eight fruit yield components. Most traits had large nonadditive gene effects, but both additive and nonadditive effects effects are important. Some maternal effects occur.

GCA and SCA effects significant for inflor. no., flower no., fruit no., and days to maturity in both generations. GCA : SCA ratios varied from 5 to 17 in the $F_{3}$ and 1.5 to more than 10 in the $F_{2}$. Cytoplasmic effects were sig. nificant in all generations and characters. segregating $F_{1}$ populations, two estimation methods: traditional-phenotypic variation from ANOVA; trg-based on interclass genetic correlation combining genetic variance components with environmental factors
GCA, SCA, and reciprocal effects significant for all characters and generations. GCA > SCA.

trg Components were considered the superior method of estimation. Fruit yield is more dependent on genolype $x$ year than on genotype $x$ block interactions. The reverse is true for fruit size. others, it was to secure strawberries with various chromosome levels or to regenerate strawberry plantlets from plant parts. One recent large experiment on inbred line development was also reported.

\section{Inbred line development}

Niemirowicz-Szczytt (1989) tried to develop $\mathrm{S}_{2}$ and $\mathrm{S}_{3}$ lines of 17 octoploid strawberry cultivars by self-pollination. It was possible to secure $S_{2}$ and $S_{3}$ generations from only 10 of the 17 original cultivars. In agreement with previous reports, reduced seed germination and plant viability, fertility, and yield were found. The number of $S_{1}$ genotypes (and hence genetic variability) was reduced in the $S_{2}$ and $S_{3}$ generations. However, considerable yield variation occurred among individuals of the $S_{2}$ generation, and among $S_{3}$ generation individuals for pollen stainability and size. Inbreeding depression was previously reported by the same author among induced polyhaploid individuals at the tetraploid $(2 n=28)$ level.

\section{Diverse (wide) hybridizations}

Wide crosses within Fragaria and among Fragaria and closely related species (chiefly Potentilla) have been made for basically two reasons. One was to introduce exotic genes into the garden strawberry, and the other was to produce polyhaploid individuals that could be doubled to yield isogenic lines.

Sukhareva (1970) reviewed the literature of apomictic development in the strawberry from remote hybridization and induced polyploidy. Tetraploid individuals arising from intercrosses of colchiploid octoploid $F$. orientalis individuals with $8 \times F$. $\times$ ananassa, $6 \times F$. moschata, or $2 \times F$. collina gave the best evidence of haploid pseudogamy (development of unfertilized haploid egg cells).

Evans (1974) reviewed the poor results reported by numerous workers from intercrosses of diploid $\times$ hexaploid and diploid $\times$ octoploid strawberry species. He then compared his own experiments crossing diploid $(2 \times)$ and amphidiploid $(4 \times)$ species or species hybrids by $F$. moschata $(6 \times)$ representative clones. The $2 \times$ by 
$6 \times$ crosses produced little or no seed and no viable seedlings. The $4 \times$ by $6 \times$ crosses produced small amounts of seed, half or more of which germinated and produced all pentaploid individuals. Four diploid species crossed by octoploid species or synthetic octoploids (colchiploid individuals from species hybrid crosses) produced little or no seed that did not germinate or produce inviable or matroclinous seedlings. In comparative crosses of diploid $(2 \times)$ and amphidiploid $(4 \times)$ species hybrids by octoploid $(8 \times)$ species or species hybrids, only the amphidploids $\times$ synthetic octoploids produced a few viable seedlings that were true hybrids and hexaploid $(6 \times)$. Evans believed that chromosomal or genic imbalance in the endosperm or between zygote and endosperm was the most likely cause of failure to produce viable strawberry plants from $2 \times$ by $6 \times$ and $2 \times$ by $8 \times$ crosses.

Evans (1977) summarized several methods of producing "synthetic" octoploid plants incorporating genetic material from Fragaria species of lower levels of ploidy. He produced six synthetic octoploids from various combinations (hybridizations and chromosome doubling) involving one hexaploid, two tetraploid, and four diploid species. Three of the synthetic octoploids were malefertile and were successfully crossed onto octoploid strawberry cultivars. Evans (1982) described the origin and intercrossing of two "multispecific" octoploids (breeding clones) derived from crossing synthetic octoploids with cultivated strawberries. The intercross of two multispecific breeding clones produced 22 seedlings. All but one of these fruited and were tolerant to common leaf diseases. Evans selected 11 clones as potential cultivars and three as parents. Two of the clones were subsequently introduced as germplasm lines.

Asker (1971) summarized the literature on intergeneric hybridization of Fragaria and Potentilla, and added several interesting observations. Some degree of success is attained only when polyploid Fragaria species are the female parents. Diploid $F$. vesca crossed by 10 Potentilla species gave sublethal hybrids and matroclinous seedlings when crossed with $P$. palustris and $P$. anserina. Hexaploid $F$. moschata by diploid $P$. fruticosa crosses averaged 10 seeds per pollination, of which $5 \%$ to $10 \%$ germinated. Fifty percent of the germinated seedlings survived to maturity and were hybrids. When octaploid Fragaria clones were used as females, hybrids were found only in crosses with diploid P. fruticosa as the male parent. Maternal ("false hybrid") strawberry seedlings resulted from crosses of octoploid Fragaria clones with pollen from P. erecta, angelica, davurica, anserina, and $4 \times$ fruticosa.

\section{Anther culture and haploid production}

Rosati et al. (1975) were not successful in producing polyhaploids from another culture of nine strawberry clones in four culture media. However, anthers of four of the clones produced normal octoploid plantlets from the undifferentiated callus, principally on the Gresshoff and Doy "1" tomato anther medium. Fifteen tetrahaploid (2n $=28$ ) plants were secured by Niemirowicz-Szczytt and Zakrzewska (1980) from the 'Redgauntlet' octoploid strawberry by culturing anthers on a Linsmaier and Skoog medium in which the cytokinin benzylaminopurine had been substituted for kinetin. The polyhaploids did not survive to maturity.

Uematsu (1980) reported a frequency of morphological variants of $7 \times 10^{-3}$ in plants of the cultivar Hohkohwase that had been produced from anther culture. These plants were rogued, and a subsample of the normal plants grown to maturity showed no fruit or plant deviations from type. Further anther culture experiments by Niemirowicz-Szczytt et al. (1983) produced 166 plants, of which 99 survived. Chromosome counts of 85 of the survivors showed that 34 were diploids $(2 \mathrm{n}=2 \mathrm{x}=14), 33$ were tetraploids $(2 \mathrm{n}$ $=4 \times=28)$, one was hexaploid $(2 n=6 x=42)$, and 17 were mixoploids. By the summer of the second year, almost all of these plants had fruited. The proportion of each ploidy level with germinable seed, the mean seed number per fruit, the percent seed germination, and pollen size classes were calculated.

Few polyhaploids had been obtained through pollination of cultivated strawberries with pollen of Potentilla anserina (4x) (Barrientos and Bringhurst, 1973) and with $P$. anserina and $P$. fruticosa pollen (Hughes and Janick, 1974). However, Jelenkovic et al. (1983) failed to secure any haploids from many octoploid and hexaploid Fragaria species flowers pollinated by diploid and tetraploid $\mathrm{PO}_{\mathrm{O}}$ tentilla species pollen. A total of 134.5 fruits bearing an estimated 46,100 seeds resulted from these pollinations. P. anserina pollen produced octoploid matroclinous seedlings (considered to be contaminants). P. fruticosu pollen produced matroclinous octoploids and intergeneric hybrids, including a sterile nonaploid $(2 n=9 x$ =63). Sayegh and Hennerty (1989) were not successful in producing strawberry haploids from anther culture, but they did secure several haploids from pollinations of several European strawberry cultivars by Potentilla fruticosa pollen, followed by aseptic embryo rescue techniques at 21 to 28 days following pollination.

\section{Ploidy manipulations}

Shoot apex treatment of rooted seedlings yielded much better survival and polyploid production than germinated seedling treatments (Sebastiampillai and Jones, 1976). A 2\% colchicine solution applied by "dropper" to the shoot apices for 24 to $48 \mathrm{hr}$ was the preferred method. A differential response to colchicine was observed within and among various diploid species and diploid and tetraploid hybrids. Niemirowicz-Szczytt et al. (1984) produced polyploids from in vitro meristem culture of $F$. vesca 'Baron Solemacher', derived from in vitro seed germination. Colchicine at $0.01 \%$ and $0.05 \%$ filtered onto the culture medium increased polyploid production. Pollen grain diameters, number of inflorescences per plant, number of seeds per fruit, and 100-seed germination rate variation were compared for diploids and tetraploids.

Fukui and Niizeki (1982) established callus cultures from shoot tips, petioles, and anthers of the octoploid cultivar Hokowase on a Linsmaier and Skoog medium to which 0 to $85 \mathrm{mg}$ of para-fluorophenylalanine (PFP)/liter had been added. Higher levels of PFP yielded a higher level of $7 \times$ (septaploid) and mixoploid plants at lower than the original $8 \times$ level. Further shoot tip culture of $7 \times$ individuals with $30 \mathrm{mg}$ of PFP/liter reduced chromosome levels of resulting plants to $6 \times$, or to a mixture of $5 x-4 x$.

\section{In vitro regeneration and selection}

Germinating seeds were proliferated on a Boxus medium to secure identical individuals from the same seed (Izak and Izhar, 1983). This procedure permitted a shortening of the breeding cycle by allowing initial selection and repeat testing to be carried on at several locations simultaneously. There appeared to be no variation among plants originated from a single seed.

Regeneration of strawberry plantlets from leaf mesophyll protoplasts was reported by Nyman and Wallin (1988). This technology is a necessary prerequisite for future somatic hybridization, gene transfer, or induction of somaclonal variation.

Malone and Dix (1986) reported an attempt at screening strawberry callus cultures and shoot tip cultures with the herbicides simazine and chlorsulphuron. Callus cultures of the strawberry clone CL-3 were not inhibited by concentrations of up to $80 \mathrm{mg}$ of simazine/liter. Strawberry shoots were sensitive to all levels (5 to 40 $\mathrm{mg} \cdot$ liter $\left.^{-1}\right)$ of simazine. Single strawberry shoots could tolerate rates of $2 \mathrm{mg}$ of simazine/liter. Strawberry shoots were treated with a 10 $\mu \mathrm{M}$ solution of nitrosomethyl urea (NMU) for $90 \mathrm{~min}$, followed by repeated washings with sterile distilled water. This mutagenic treatment resulted in 25 of 64 shoots tolerating subsequent exposure to 10 , but not $20, \mathrm{mg}$ of simazine/liter. Chlorsulphuron was toxic to callus cultures of CL-205 strawberry. A very low concentration (0.003 mg.liter $\left.{ }^{-1}\right)$ allowed some growth of preestablished callus, but inhibited callus formation on leaf explants of strawberry. These results suggest that callus or cell suspension cultures would be suitable for resistance testing.

\section{INHERITANCE PATTERNS}

Our understanding of strawberry inheritance patterns has been expanded by many studies over the past 20 years, as demonstrated by examples of studies on Mendelian and quantitative inheritance. 


\section{Mendelian inheritance}

In the diploid wood strawberry (Fragaria vesca L.), non-runnering $(r / r)$, the everbearing habit $(j / j)$, and the arborea (long internode, runner-forming, non-crown-forming) type (arb/arb) had previously been shown to be homozygous recessive mutants. Guttridge (1973) studied segregation in a cross between a long-stemmed type ( $F$. vesca $L$. arborea Staudt) and an alpine (non-runnering) everbearing clone ( $F$. vesca semperflorens Duch., 'Baron Solemacher'). Only three of the expected four classes of everbearing segregants occurred. The non-runnering, arboreal, everbearing type (rr, arb arb, ij) was missing, suggesting that the arboreal gene in the double recessive is epistatic to the gene for runner formation. This was confirmed from backcross studies because double homozygous arboreal runnering ( $\mathrm{arb} / \mathrm{arb},+/+)$ and double homozygous arboreal non-runnering (arb/arb, r/r) segregants both had similar runners and runnering habits.

Arulsekar and Bringhurst (1981) proposed a single locus, threeallele model for the phosphoglucoisomerase (PGI; EC 5.3.1.4) allozymes observed in California populations of diploid Fragaria vesca. They designated the alleles Pgi- $2^{\mathrm{b}}$, Pgi- $2^{\mathrm{c}}$, and Pgi- $2^{\mathrm{d}}$, and offered evidence of three additional alleles at this locus in other European and Asiatic diploid Fragaria species.

Arulsekar et al. (1981) proposed a tentative four-locus genetic model for octoploid strawberries at the PGI-2 locus, in which the four "loci" represent the gene site on the four homologous genomes of the cultivated strawberry (Fragaria $\times$ ananassa Duch.). Two of the four loci with four alleles were found in $F$. ananassa cultivars. The other two loci were inferred from banding patterns in the octoploid $F$. chiloensis and in pentaploid $F$. chiloensis $\times F$. vesca hybrids. These isozyme analyses give additional support to the highly diploidized nature of $F$. $\times$ ananassa.

Oydvin (1980) determined that appressed stem pedicel pubescence (ss) is a monogenetic recessive to spreading hairs $(S)$ in octoploid cultivated strawberries. The cultivars Abundance, Dybdahl, and Soltwedel have appressed stem hairs. Cultivars with spreading pubescence were found to be either heterozygous (Ss) ('Pocahontas', 'Tamella', and 'Zefyr') or homozygous dominant (SS) ('Belrubi', 'Glima', 'Redland Crimson', and 'Senga Sengana') for the trait.

Van de Weg et al. (1989) determined inheritance of resistance to an undetermined race of Phytophthora fragariae (red stele root rot) in a field near Zundert, Netherlands. Parents of 24 tested seedling progenies segregated into the classes: completely resistant (six American cultivars and selections from the Beltsville, Md. program), a high level of partial resistance (United Kingdom, 'Cambridge Favourite'), and a low level of partial resistance (eight Dutch cultivars and selections). The proportions of symptomless seedlings from completely resistant by partially resistant (susceptible) parent crosses was usually about 50\%, suggesting that the American parents had one major resistance gene effective against the race(s) present in the test field. Van de Weg (1989a, 1989b) reinterpreted his own data and that of others concerning red stele root rot on the basis of a gene-for-gene system. In his proposed model, there are at least five host resistance and five fungal virulence genes. Proposed virulence genes were assigned to many of the known red stele fungus races, and proposed resistance genes were assigned to the differential cultivars used by plant pathologists to discriminate among the fungal races. Seventeen of 18 resistant by susceptible crosses fit the expected model (50\% symptomless seedlings expected). A review of host-pathogen interaction studies for fungus races A-1 to A-6 from the literature showed that 26 of 40 reports agreed with the proposed, five gene-for-gene model.

\section{Quantitative inheritance}

There has been a proliferation of quantitative strawberry inheritance information during the review period (Table 2). The studies have ranged from statistical analyses of progeny mean differences of scores to sophisticated heritability determinations, including variance partitioning into types of genetic vs. phenotypic or environmental contributions. Several elegant multivariate analyses are also included. It should be stressed that the results of individual quantitative studies cannot be generalized, but depend on the composition of the test strawberry population, interactions with the environments in which they are grown, and the analytical methods used.

Genetic variability was determined for diverse characters by various authors. Methods and findings are summarized in Table 3.

\section{Literature Cited}

Aalders, L.E. and D.L. Craig. 1974. Analysis of fruit yield and related factors in a diallel of seven inbred strawberry clones. Can. J. Genet. Cytol. 16:381-387.

Aruisekar, S. and R.S. Bringhurst. 1981. Genetic model for the enzyme marker PGI in diploid California Fragaria vesca L. J. Hered. 73:117120

Arulsekar, S., R.S. Bringhurst, and V. Voth. 1981. Inheritance of PGI and LAP isozymes in octoploid cultivated strawberries. J. Amer. Soc. Hort. Sci. 106:679-683.

Asker, S. 1971. Some viewpoints on Fragaria $\times$ Potentilla intergeneric hybridization. Hereditas 67:181-190.

Barrientos, F. and R.S. Bringhurst. 1973. A haploid of an octoploid strawberry cultivar. HortScience 8:44.

Barritt, B.H. 1976. Evaluation of strawberry parent clones for easy calyx removal. J. Amer. Soc. Hort. Sci. 101:590-591.

Barritt, B.H., R.S. Bringhurst, and V. Voth. 1982. Inheritance of early flowering in relation to breeding day-neutral strawberries. J. Amer. Soc. Hort. Sci. 107:733-736

Barritt, B.H. and H.A. Daubeny. 1982. Inheritance of virus tolerance in strawberry. J. Amer. Soc. Hort. Sci. 107:278-282.

Barritt, B.H. and C.H. Shanks, Jr. 1980. Breeding strawberries for resistance to the aphids Chaetosiphon fragaefolii and C. thomasi. HortScience 15:287-288.

Barritt, B.H. and C.H. Shanks, Jr. 1981. Parent selection in breeding strawberries resistant to twospotted spider mites. HortScience 16:323-324.

Berezenko, N.P. 1976. Meiosis in sterile garden strawberry-hautboy strawberry hybrids and-in cultivated strawberry (In Russian). Tsitologiya i Genetika 10:49-52.

Berezenko, N.P. 1981. Study of meiosis in the hautboy strawberry and sterile strawberry-hautboy hybrids (In Russian). Tsitologiya i Genetika 15:37-40

Bringhurst, R.S., S. Arulsekar, J.F. Hancock, Jr., and V. Voth. 1981. Electrophoretic characterization of strawberry cultivars. J. Amer. Soc. Hort. Sci. 106:684-687.

Brown, G.R., J.N. Moore, and L.F. Bailey. 1975. Evaluating genetic sources of fruit detachment traits in strawberry. HortScicnce 10:120-121.

Bvrne, D. and G. Jelenkovic. 1976. Cytological diploidization in the cultivated octoploid strawberry Fragaria xananassa. Can. J. Genet. Cytol. 18:653-659.

Crock, J.E., C.H. Shanks, Jr., and B.H. Barritt. 1982. Resistance in Fragaria chiloensis and $F$. $\times$ ananassa to the aphids Chaetosiphon fragaefolii and C. thomasi. HortScience 17:959-960.

Daniels, R.R., G.D. Kuhn, S.H. Hampson, C.M. Ritter, and C. Miller. 1982. Freezing quality examined for 7 strawberry varieties. Science in Agr. Pa. Agr. Expt. Sta. 29:14-15.

Darrow, G.M. 1937. Strawberry improvement. Better plants and animals II. U.S. Dept. Agr. Yrbk. of Agr. 1937, p. 445-495.

Darrow, G.M. 1966. The strawberry-history, breeding and physiology. Holt, Rinehart and Winston, New York.

Daubeny, H.A., R.A. Norton, and B.H. Barritt. 1972. Relative differences in virus tolerance among strawberry cultivars and selections in the Pacific Northwest. Plant Dis. Rptr. 56:792-795.

Doss, R.P., C.H. Shanks, Jr., J.D. Chamberlain, and J.K.L. Garth. 1987. Role of leaf hairs in resistance of a clone of beach strawberry, Fragaria chiloensis, to feeding by adult black vine weevil, Otiorhynchus sulcatus (Coleoptera: Curculionidae). Environ. Entomol. 16:764-768.

Durner, E.F. and E.B. Poling. 1986. Ribbon row production of six strawberry cultivars grown at six spacings on raised and flat beds in southeastern North Carolina. Adv. Strawberry Prod. 5:1-6.

Edwards, W.H., R.K. Jones, and D.P. Schmitt. 1985. Host suitability and parasitism of selected strawberry cultivars by Meloidogyne hapla and $M$. incognita. Plant Dis. 69:40-42.

Evans, W.D. 1974. Evidence of a crossability barrier in diploid $\times$ hexaploid and diploid $\times$ octoploid crosses in the genus Fragaria. Euphytica 23:95100.

Evans, W.D. 1977. The use of synthetic octoploids in strawberry breeding. Euphytica 26:497-503.

Evans, W.D. 1982. The production of multispecific octoploids from Fragaria species and the cultivated strawberry. Euphytica 31:901-907. 
Fukui, K. and H. Niizeki. 1982. Artificial reduction of chromosome number in Fragaria ananassa following treatment p-fluoro-phenylalanine, p. 427428. In: A. Fujiieara (ed.). Proc. 5th Intl. Congr. Plant Tissue and Cell Culture, Tokyo, Japan. 11-16 July 1982.

Gooding, H.J., D.L. Jennings, and P.B. Topham. 1975. A genotype-environment experiment on strawberries in Scotland. Heredity 34:105-115.

Guttridge, C.G. 1973. Stem elongation and runnering in the mutant strawberry: Fragaria vesca L. arborea Staudt. Euphytica 22:357-361.

Hancock. J.F.. J. Sietker. N. Schulte. and M.P. Pritts. 1982. The effect of plant spacing and runner removal on twelve strawberry cultivars. Adv. Strawberry Prod. 1:1-3.

Hortynski, J.A. 1979. Correlation and path analysis in strawberry seedlings (Fragaria ananassa Duch.). Genet. Polonica 20:549-566.

Hortynski, J.A. 1980. Variability and heritability of some quantitative characters in strawberry seedlings (Fragaria ananassa Duch.). Genet. Polonica 21:69-81.

Hortynski, J. 1989. Genotype-environmental interaction in strawberry breeding. Acta Hort. 265:175-179.

Hughes, H.G., and J. Janick. 1974. Production of tetrahaploids in the cultivated strawberry. HortScience 9:442-444.

Ibrahim, A.M.F., K. Sadanaga, and E.L. Denisen. 1981. Chromosomal behavior in octoploid strawberry progenies and their parental clones during meiosis. J. Amer. Soc. Hort. Sci. 106:522-526.

Ichijima, K. 1926. Cytological and genetic studies on Fragaria, Genetics 11:590-604.

Izsak, E. and S. Izhar. 1983. Rapid micropropagation of strawberry plantlets from seeds for breeding purposes. Acta Hort. 131:101-103.

Jelenkovic, G., M.L. Wilson, and P.J. Harding. 1984. An evaluation of intergeneric hybridization of Fragaria spp. $\times$ Potentlla spp. as a means of haploid production. Euophytica 33:143-152.

Jennings, D.L. 1989. The use of multivariate analyses for study of autumnfruiting strawberries. Acta Hort. 265:91-96.

Lacey, C.N.D. 1973. Phenotypic correlations between vegetative characters and yield components in strawberry. Euphytica 22:546-554.

Lal, S.D. and J.N. Seth. 1979. Studies on genetic variability in strawberry. (Fragaria ×ananassa Duch.) Prog. Hort. 11:49-53.

Lal, S.D. and J.N. Seth. 1980. Correlation studies in strawberry (Fragaria $\times$ ananassa Duch). Indian J. Hort. 37:371-375.

Lal, S.D. and J.N. Seth. 1981. Studies on combining ability in strawberry (Fragaria $\times$ ananassa): I. Number of inflorescences, number of flowers, days to maturity and number of fruits. Can. J. Genet. Cytol. 23:373378.

Lal, S.D. and J.N. Seth. 1982. Studies on combining ability in strawberry $($ Fragaria $\times$ ananassa): II. Fruit length, fruit diameter, fruit weight, ascorbic acid, total soluble solids and fruit yield. Can. J. Genet. Cytol. 24:479-483.

Lawrence, F.J. and L.W. Martin. 1980. Breeding strawberries for machine harvest in the Pacific Northwest. Ore. State Univ. Agr. Expt. Sta. Bul 645:30-37.

Longley, A.F. 1926. Chromosomes and their significance in strawberry classification. J. Agr. Res. 32:559-568.

Maas, J.L., G.J. Galletta, and A.D. Draper. 1989. Resistance in strawberry to races of Phytophthora fragariae and to isolates of Verticillium from North America. Acta Hort. 265:521:526.

Malone, R.P. and P.J. Dix. 1986. Selection for herbicide resistance in tissue cultures of Fragaria and Nicotiana, p. 479-486. In: L.A. Withers and P.G. Alderson (eds,). Plant tissue culture and its agricultural applications. Butterworths, London.

Melville, A.H., A.D. Draper, and G.J. Galletta. 1980a. Transmission of red stele resistance by inbred strawberry selections. J. Amer. Soc. Hort Sci. 105:608-610.

Melville, A.H., G.J. Galletta, A.D. Draper, and T.J Ng. 1980b. Seed germination and early seedling vigor in progenies of inbred strawberry selections. HortScience 15:749-750.

Mok, D.W.S. and W.D. Evans. 1971. Chromosome associations at diakinesis in the cultivated strawberry. Can. J. Genet. Cytol. 13:231-236

Moore, J.N. and W.A. Sistrunk. 1980. Breeding strawberries for harvest mechanization in Arkansas. Ore. State Univ. Agr. Expt. Sta. Bul. 645:2529

Nicoll, M.F. and G.J. Galletta. 1987. Variation in growth and flowering habits' of Junebearing and everbearing strawberries. J. Amer. Soc. Hort. Sci. 112:872-880.

Niemirowicz-Szczytt, K. 1989. Preliminary studies on inbreeding in strawberry Fragaria ×ananessa Duch. Acta Hort. 265:97-104.

Niemirowicz-Szczytt, K., B. Ciupka, and S. Malepszy. 1984. Polyploids from Fragaria vesca $\mathrm{L}$. meristems, induced by colchicine in the in vitro culture. Bul. L'Acad. Polon. Sci., Ser. Sci. Biol. 32:57-63.

Niemirowicz-Szczytt, K. and Z. Zakrzewska. 1980. Fragaria $\times$ ananassa anthers culture. Bul. L'Acad. Polon. Sci., Ser. Sci. Biol. 28:341-347.
Niemirowicz-Szczytt, K., Z. Zakrzewska, S. Malepszy, and B. Kubicki. 1983. Characters of plants obtained from Fragaria $\times$ ananassa in anther culture. Acta Hort. 131:231-237.

Nyman, M. and A. Wallin. 1988. Plant regeneration from strawberry (Fragaria $\times$ ananassa) mesonphyll protonlasts. J. Plant Physiol. 133:375-377.

Oydvin, J. 1980. Inheritance of type of pubescence on the pedicels of strawberries (Fragaria $\times$ ananassa Duschesne) (In Norwegian). Meldinger fra Norges Landbrukshogskole 59:1-9.

Pelofske, P.J. and F.J. Lawrence. 1984. Inheritance of size relationship of primary and secondary berries of strawberry. HortScience 19:641-642.

Popenoe, J. and H.J. Swartz. 1985. Yield component comparison of strawberry plants grown in various cultural systems. Adv. Strawberry Prod. 4:10-14.

Popova, I.V., A.E. Konstantinova, A.U. Zekalashivili, and B.Kh. Zhananov. 1985. Features of breeding strawberries for resistance to berry molds. Soviet Agr. Sci. 1985(3):29-33.

Powers, L. 1944. Meiotic studies of crosses between Fragaria ovalis and Fragaria ananassa. J. Agr. Res. 69:435-448.

Rosati, P., M. Devreux, and U. Laneri. 1975. Anther culture of strawberry. HortScience 10:119-120.

Sayegh, A.J. and M.J. Hennerty 1989. Androgenensis and embryo rescue for strawberry haploid production. Acta Hort. 265:129-135.

Scott, D.H. and F.J. Lawrence. 1975. Strawberries, p. 71-97. In: J. Janick and J.N. Moore (eds.). Advances in fruit breeding. Purdue Univ. Press. West Lafayette. Ind.

Sebastiampillai, A.R. and J.K. Jones. 1976. Improved techniques for the induction and isolation of polyploids in the genus Fragaria. Euphytica 25:725-732.

Shanks, C.H., Jr., D.L. Chase, and J.D. Chamberlain. 1984. Resistance of clones of wild strawberry, Fragaria chiloensis, to adult Otiorhynchus sulcatus and O. ovatus. Environ. Entomol. 13:1042-1045.

Shaw, D.V. 1988. Genotypic variation and genotypic correlations for sugars and organic acids of strawberries. J. Amer. Soc. Hort. Sci. 113:770774.

Shaw, D.V., R.S. Bringhurst, and V. Voth. 1988. Quantitative genetic variation for resistance to leaf spot (Ramularia tulasnei) in California strawberries. J. Amer. Soc. Hort. Sci. 113:451-456.

Shuster, D.J., J.F. Price, F.G. Martin, C.M. Howard, and E.E. Albregts. 1980. Tolerance of strawberry cultivars to two-spotted spider mites in Florida. J. Econ. Entomol. 73:52-54.

Simpson, D.W. 1987. The inheritance of mildew resistance in everbearing and day-neutral strawberry seedlings. J. Hort. Sci. 62:329-334.

Sistrunk, W.A. and J.N. Moore. 1980. Evaluating strawberry selections for mechanization and high quality. Ore. State Univ. Agr. Expt. Sta. Bul. 645:133-143.

Sjulin, T.M. and A. Dale. 1987. Genetic diversity of North American strawberry cultivars. J. Amer. Soc. Hort. Sci. 112:375-385.

Sjulin, T.M., J. Robbins, and B.H. Barritt. 1986. Selection for virus tolerance in strawberry. J. Amer. Soc. Hort. Sci. 111:458-464.

Skrede, G. 1980. Strawberry varieties for industrial jam production. J. Sci. Food Agr. 31:3670-676.

Spangelo, L.P.S., C.S. Hsu, S.O. Fejer, P.R. Bedard, and G.L. Rousselle. 1971. Heritability and genetic variance components for 20 fruit and plant characters in the cultivated strawberry. Can. J. Genet. Cytol. 13:443456.

Staudt, G. 1951. Über Fragen der phylogenetischen Entwicklung eineger Arten der Gattung Fragaria. Züchter 21:222-232.

Staudt, G. 1952. Cytogenetische Untersuchungen as Fragaria orientalis Los. und ihre Bedeuting fur Artbildung und-Geschlechtidifferenzierung in der Gattung Fragaria L.Z. Induktive Abstammungs Verebungslchre 84:36-416.

Strik, B.C. and J.T.A. Proctor. 1988. Yield component analysis of strawberry genotypes differing in productivity. J. Amer. Soc. Hort. Sci. 113:124129.

Sukhareva, N.B. 1970. Elements of apomixis in strawberry, p. 120-123 In: S.S. Khokhlov (ed.) Apomixis and breeding. (Translated from Russian, 1976).

Swartz, H.J., J. Popenoe, and J.A. Fiola. 1985. Yield component analysis of the 1984 Maryland-USDA replicated trials. Adv. Strawberry Prod. $4: 45-52$.

Swartz, H.J., C.S. Walsh, A.F. Geyer, L. Douglass, G.J. Galletta, and R.H. Zimmerman. 1982. Plant crown competition in strawberry matted rows. Adv. Strawberry Prod. 1:6-11.

Szczygiel, A. and J. Danek. 1984. Trials of breeding strawberry cultivars resistant to the northern root-knot nematode, Meloidogyne hapla Chitw. Fruit Sci. Rpt. 11:79-85.

Uematsu, Y. 1980. Frequency of variants appearing on breeding a lot of virus-free strawberry plants by means of another culture method (In Japanese). Bul. Shikoku Agr. Bxpt. Sta. 25:7-10 
ukin, N.V., V.V. Kichina, and I.V. Popova. 1976. Evaluation of several strawberry varieties based on their combining ability (In Russian). Sov. Genet. 12:1483-1488.

Van de Weg, W.E. 1989a. Cultivar-race interactions of the strawberryPhytophthora fragariae system with regard to a gene-for-gene model. Acta Hort. 265:203-206.

Van de Weg, W.E. 1989b. Genetics of resistance to Phytophthora fragariae Hickman in strawberry. Acta Hort. 265:143:148.

Van de Weg, W.E., L.M. Wassenaar, and C.P.J. Lindeloof. 1989. Inher- itance of resistance to Phytophthora fragariae Hickman in strawberry. Euphytica 42:25-30.

Watkins, R. and L.P.S. Spangelo. 1971. Strawberry selection index components. Can. J. Genet. Cytol. 13:42-50.

Wenzel, W.G. 1980. Correlation and selection indices in strawberry breeding. Agroplantae 12:29-32.

Zubov, A.A. and K.V. Stankevich. 1982. Combining ability of a group of strawberry varieties for quality characters of the fruits (In Russian). Sov. Genetics 18:732-739. 